\title{
An Indirect Immunoradiometric Assay of Microbes
}

\author{
By R. E. STRANGE AND P. HAMBLETON \\ Microbiological Research Establishment, Porton Down, Salisbury SP4 OJG, Wilts
}

(Received 3I October 1975)

\section{INTRODUCTION}

Direct assays for the rapid detection and determination of sparse microbial populations using radioactively-labelled antibodies and Millipore membrane filtration have been reported by Strange, Powell \& Pearce (I97I) and Strange \& Martin (1972). They also described an indirect assay involving successive treatments of samples with anti-bacterial globulins and ${ }^{125}$ I-labelled homologous antiglobulin, but this was less sensitive and precise than the direct assay. Recently, J. E. Benbough and K. L. Martin (personal communication) have developed an improved indirect radio-assay which involves successive treatments of bacteria filtered on to the surface of a Fluoropore membrane (FGLP; Millipore) with anti-bacterial globulins and ${ }^{3} \mathrm{H}$-labelled antiglobulins. They claim this method is precise and reproducible with a higher sensitivity than that of a direct assay on Fluoropore membranes. We attempted to simplify and improve the sensitivity of the indirect assay for microbial assessment purposes, and showed that bacteria can be assayed by reaction with suitable concentrations of immunopurified anti-bacterial globulins and ${ }^{125}$ I-labelled homologous antiglobulins, added to the reaction mixture simultaneously.

\section{METHODS}

Micro-organisms. Washed suspensions of Escherichia coli (MREI62), Serratia marcescens (8UK), Francisella tularensis (live vaccine strain) and purified Bacillus subtilis var. niger spores were prepared and assessed as described by Strange \& Martin (I972).

Solutions. Saline phosphate buffer contained $0 . \mathrm{I} \mathrm{I} \mathrm{M}-\mathrm{NaCl}$ and $0.02 \mathrm{M}$-sodium phosphate, $\mathrm{pH} 7 \cdot 7$, in glass-distilled water. Saline phosphate buffer + Brij 35 contained $1 \%(\mathrm{w} / \mathrm{v})$ polyoxyethylene lauryl ether (Brij 35; BDH).

Immuno-purified antibodies. Purified rabbit anti-bacterial globulins were prepared as described previously (Strange et al., I97 I Strange \& Martin, 1972). Immuno-purified sheep anti-rabbit (SAR) globulin was prepared by absorbing sheep antiserum $(36 \mathrm{ml})$ with $\mathrm{CNBr}$ activated Sepharose (Pharmacia; I g) linked to normal rabbit globulins (50\% saturated ammonium sulphate precipitate of normal rabbit serum; reprecipitated twice and dialysed until free of detectable ammonium ion) as described in Pharmacia's instruction sheet. The resulting complex was separated on a sintered glass filter (grade 2), washed thoroughly with $0.9 \% \mathrm{NaCl}$ and dissociated in $0.1 \mathrm{M}$-acetic acid $(30 \mathrm{ml})$ for $\mathrm{I}$ h at $37^{\circ} \mathrm{C}$ (Hill, 1972). The suspension was filtered on sintered glass and the filtrate neutralized to $\mathrm{pH} 7 \cdot 0$. The extract was concentrated to about $2 \mathrm{ml}$ by pressure dialysis and centrifuged (I7000 $\mathrm{g}$; $10 \mathrm{~min}$ ). Protein was precipitated with an equal volume of saturated (at $20^{\circ} \mathrm{C}$ ) ammonium sulphate, dissolved in saline phosphate buffer $\mathrm{pH} 7 \cdot 7$, reprecipitated twice with ammonium sulphate, redissolved in saline buffer and dialysed against the same buffer until free of detectable ammonium ion. After removing insoluble material by centrifuging, the yield of soluble antibody protein depended on the immunological activity of the parent antiserum : $36 \mathrm{ml}$ of 
good antiserum provided Io to $15 \mathrm{mg}$ antibody suitable for use in the assay. According to double diffusion tests in agar plates (Ouchterlony, 1953) and based on the respective protein contents of samples, the specific precipitating activity of purified SAR globulin was about 20 -fold that of the parent antiserum proteins.

Radioactive labelling of antibody. Immuno-purified SAR globulins were iodinated with ${ }^{125}$ I (carrier-free, free from reducing agent; The Radiochemical Centre, Amersham, Buckinghamshire) using the method of Hunter \& Greenwood (1962) described by Strange et al. (197I). Usually, $270 \mu \mathrm{g} \mathrm{SAR}$ globulins were reacted with $0.5 \mathrm{mCi}{ }^{125} \mathrm{I}$ of which about $85 \%$ was taken up giving a product with specific activity of about $\mathrm{I} \cdot 5 \mu \mathrm{Ci}$ ( $\mu$ g protein) ${ }^{-1}$. After labelling and separation, the antibody solution was mixed with clarified normal sheep serum (I/6th final volume) and diluted to $6 \mathrm{ml}\left(45 \mu \mathrm{g} \mathrm{SAR}\right.$ globulins $\left.\mathrm{ml}^{-1}\right)$.

Indirect immunoradiometric assay. Diluents and antibody reagents were filtered through Millipore membranes $(0 \cdot 22 \mu \mathrm{m})$ immediately before use. To triplicate samples (usually $0 \cdot 1 \mathrm{ml}$ ) of bacterial suspensions and saline phosphate buffer alone in disposable plastic tubes $(7.5 \mathrm{~cm}, \mathrm{I} \mathrm{cm}$ diam) were added immuno-purified anti-bacterial globulins $(50 \mu 1$ containing $0.88 \mu \mathrm{g}$ antibody protein and one sixth volume of normal sheep serum), ${ }^{125}$ I-labelled SAR reagent ( $50 \mu \mathrm{l}$; about $2 \cdot 3 \mu \mathrm{g}$ SAR globulins; about $\mathrm{r} \cdot 5 \mu \mathrm{Ci} \mu \mathrm{g}^{-1}$ ), and saline phosphate buffer to give a final volume of $0.25 \mathrm{ml}$. Reaction mixtures were held at $25{ }^{\circ} \mathrm{C}$ for $3 \mathrm{~h}$ then filtered and washed on Millipore membranes ( 0.45 or I $\cdot 2 \mu \mathrm{m}$; see Results) with saline phosphate buffer + Brij 35 (Strange et al., I97I). The filtration areas of the filters were punched out and their radioactivities measured.

Measurement of radioactivity. An automatic gamma counter (Nuclear Enterprises Ltd, Sighthill, Edinburgh EHI I ${ }_{4} \mathrm{EY}$; model 83I I) was used. Counts were collected for I min with a counting efficiency of about $50 \%$.

\section{RESULTS}

Sensitivity of the assay depends on the level and reproducibility of the blank (no bacteria) value, which largely depends on the extent to which insoluble radioactive complexes are formed and retained on the membrane filters. Using the concentrations of rabbit antibacterial and anti-rabbit globulins given in Methods, and filtering reaction mixtures through $0.45 \mu \mathrm{m}$ Millipore membranes, blank values with $S$. marcescens, $F$. tularensis and $B$. subtilis spore antibodies were usually low (I to 4 c.p.s.). In contrast, the anti-O8 globulin used to assay E. coli MREI $62(\mathrm{O} 8: \mathrm{K} 9)$ gave high blank values (up to $40 \mathrm{c} . \mathrm{p} . \mathrm{s}$.) but these were decreased ( 8 to Io c.p.s., without significant loss of signal in the presence of bacteria) by using $\mathrm{I} \cdot 2 \mu \mathrm{m}$ instead of $0.45 \mu \mathrm{m}$ Millipore membranes. A comparison of assays in which the two antibodies were added together with those in which antiglobulin was added after reaction of bacteria with anti-bacterial globulin, showed that blank responses were similar and test responses somewhat higher with the former procedure.

\section{Rate of uptake of ${ }^{125}$ I-labelled SAR globulin}

Radioactive signals (minus blank values) given by $10^{6} \mathrm{~S}$. marcescens after reaction with $0.88 \mu \mathrm{g}$ anti-S. marcescens globulin and $2.3 \mu \mathrm{g}{ }^{125}$ [-labelled SAR globulin in a reaction volume of $0.25 \mathrm{ml}$ for $\mathrm{I}, 2,4$ and $6 \mathrm{~h}$ at $25^{\circ} \mathrm{C}$, were $147,223,369$ and $5 \mathrm{I} 5 \mathrm{c}$.p.s., respectively. The blank response also increased with reaction time ( $\mathrm{r} \cdot 3$ c.p.s. after $\mathrm{I} h$ and $8 \cdot 4$ c.p.s. after $6 \mathrm{~h}$ ) and an incubation period of about $3 \mathrm{~h}$ was selected to give the maximum ratio of test response to blank response. Attempts to reach saturation more rapidly by increasing the concentration of labelled antiglobulin gave unacceptably high and variable blank values. 


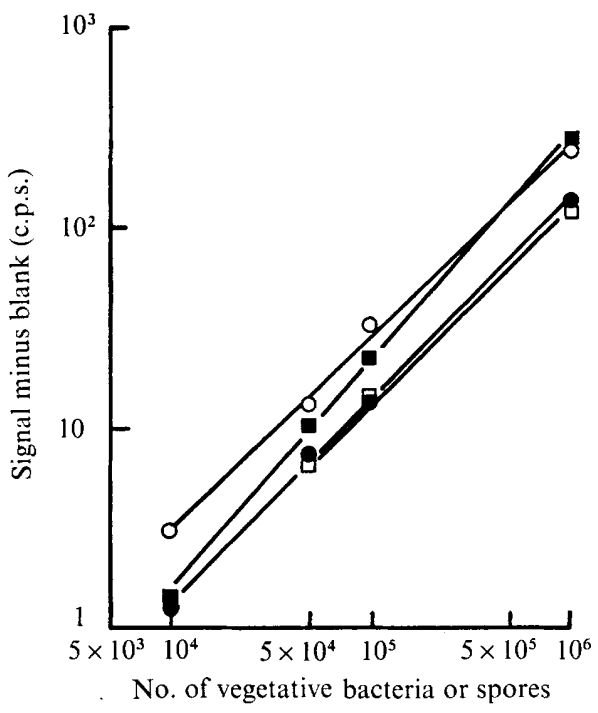

Fig. I. Triplicate samples $(0.1 \mathrm{ml})$ of suspensions containing $10^{4}$ to $10^{6}$ bacteria and saline phosphate buffer were incubated for $3 \mathrm{~h}$ at $25^{\circ} \mathrm{C}$ with homologous anti-bacterial globulin (5o $\mu \mathrm{l}$ containing $0.88 \mu \mathrm{g}$ antibody and one-sixth volume of normal sheep serum) and ${ }^{125}$ I-labelled sheep anti-rabbit globulin reagent (50 $\mu \mathrm{l} ; 2.3 \mu \mathrm{g}$ antibody; about $\mathrm{I} \cdot 5 \mu \mathrm{Ci} \mu \mathrm{g}^{-1}$ ) in a total volume of $0.25 \mathrm{ml}$. Reaction mixtures were filtered on Millipore membrane filters $(0.45 \mu \mathrm{m}$, except for $E$. coli assays when $\mathrm{I} \cdot 2 \mu \mathrm{m}$ filters were used) and radioactivities of the punched-out membrane centres determined. Mean radioactive signais (minus blank values) are shown for $(O) S$. marcescens, (৩) F. tularensis, ( $\square$ ) E. coli MREI62, and (ם) B. subtilis spores.

Responses with vegetative bacteria and bacterial spores

When samples of washed suspensions of $S$. marcescens, $F$. tularensis and $B$. subtilis spores were assayed, a minimum of $10^{4}$ of each organism was detected and responses increased with the number of organisms up to $10^{6}$ organisms at least (Fig. I). With $E$. coli the assay was less sensitive, requiring at least $5 \times 10^{4}$ bacteria for detection.

\section{Specificity}

Responses were insignificant when the bacteria were incubated with heterologous antibacterial globulins and labelled antiglobulin. In the absence of anti-bacterial globulins, none of the bacteria took up detectable amounts of labelled antiglobulins.

\section{Multibacterial species screening}

The possibility that samples containing unidentified bacteria could be screened by reacting them with a mixture of anti-bacterial globulins and labelled antiglobulin was investigated. When samples of each of the four organisms were reacted with a mixture of the four homologous anti-bacterial globulins $(0.22$ or $0.44 \mu \mathrm{g}$ of each) and labelled antiglobulin (2.3 or $4.6 \mu \mathrm{g}$, respectively) for $2.5 \mathrm{~h}$, responses were less reproducible and blank values higher than with a single anti-bacterial globulin. In general, a minimum of $5 \times \mathrm{IO}^{4}$ bacteria was detectable; above this number results were more reproducible. 


\section{Use of crude anti-bacterial globulins}

The requirement for immuno-purified anti-bacterial globulins is a disadvantage but attempts to use salt-precipitated globulin fractions of antisera instead were only partially successful. The non-specific globulins in the fraction combine with labelled antiglobulin, thus decreasing the concentration of the latter available to react with anti-bacterial antibody. To counteract this, several modified assays were tested, including a two-stage reaction in which the complex was separated and washed after the first reaction. However, sensitivity was lower (a minimum of $10^{5}$ bacteria detectable) and reproducibility less satisfactory than with the one-stage reaction using immuno-purified anti-bacterial globulin.

\section{Assay of viruses}

The possibility that viruses could be specifically determined by this method was tested using coliphage $\mathrm{T}_{7}$. When reaction mixtures containing purified $\mathrm{T}_{7}$ (Strange \& Martin, 1972), immuno-purified anti-T 7 globulin and labelled SAR globulin were incubated for $3 \mathrm{~h}$ and filtered on $0.45 \mu \mathrm{m}$ Millipore membranes, radioactive signals (minus blank value, 62 c.p.s.) for $4 \times 10^{6}, 4 \times 10^{7}$ and $4 \times 10^{8}$ total phage particles were 22,82 and 664 c.p.s. respectively. These results suggest that specific determination of animal viruses by this method is feasible.

\section{DISCUSSION}

Compared with the direct radio-antibody assay (Strange et al., I97I), the indirect assay reported here is less sensitive and less rapid. The main advantage is that only one labelled antibody (antiglobulin) is required for identification and determination of a variety of microbial species. ${ }^{125} \mathrm{I}$-labelled antiglobulin of relatively low specific radioactivity (I to 2 $\mu \mathrm{Ci} \mu \mathrm{g}^{-1}$ ) has a useful life of at least a week and gave a higher detection sensitivity than ${ }^{3} \mathrm{H}$-labelled antiglobulin used in the same assay system.

We thank Dr J. E. Benbough and Mr K. L. Martin for details of their assay and providing ${ }^{3} \mathrm{H}$-labelled sheep anti-rabbit globulin.

\section{REFERENCES}

HILL, R. J. (1972). Elution of antibodies from immunoadsorbents: effect of dioxane in promoting release of antibody. Journal of Immunological Methods I, 23I-245

Hunter, W. M. \& GREenwood, F. C. (1962). Preparation of iodine-13I labelled human growth hormone of high specific activity. Nature, London I94, 495-496.

OUCHTERLONY, O. (1953). Antigen-antibody reactions in gels. IV. Types of reactions in coordinated systems of diffusion. Acta pathologica et microbiologica scandinavica 32, 23I-240.

STRANGE, R. E. \& MARTIN, K. L. (I972). Rapid assays for the detection and determination of sparse populations of bacteria and bacteriophage $\mathrm{T}_{7}$ with radioactively labelled homologous antibodies. Journal of General Microbiology 72, 127-141.

Strange, R. E., Powell, E. O. \& Pearce, T. W. (197I). The rapid detection and determination of sparse microbial populations with radioactively labelled antibodies. Journal of General Microbiology 67, 349357. 